\title{
CORPORATE DECISION MAKING DALAM KOMUNIKASI ORGANISASI
}

\author{
Rebekka Rismayanti \\ Fakultas Ilmu Sosial dan Ilmu Politik \\ Universitas Atma Jaya Yogyakarta \\ rebekka.risma@gmail.com
}

\begin{abstract}
In an organization, decision making is anessential factor to achieve its goals. The decision-making process is a process of selecting the best alternative from many alternatives that systematically chosen as a way to resolve the problem. The decision is seen as a "choice between the alternatives" as well as a form of communication that fulfills the social expectations of the organization's members. So the goal setting, onflow of information as well as individual's values within the group affect the decisions made by the group itself. Then, the leadership-participation style in decision-making is the most important factor for creating the mutual understanding between both parties related to the decision.
\end{abstract}

\begin{abstract}
Abstrak
Dalam sebuah organisasi, pengambilan keputusan merupakan faktor penting untuk mencapai tujuannya. Proses pengambilan keputusan adalah proses pemilihan alternatif terbaik dari berbagai alternatif yang secara sistematis dipilih sebagai cara untuk menyelesaikan masalah. Keputusan ini dipandang sebagai "pilihan antara alternatif" serta bentuk komunikasi yang memenuhi harapan sosial dari anggota organisasi. Jadi penetapan tujuan, aliran informasi serta nilai-nilai individu dalam kelompok mempengaruhi keputusan yang dibuat oleh kelompok itu sendiri. Kemudiangaya kepemimpinan-partisipasi dalam pengambilan keputusan adalah faktor yang paling penting untuk menciptakan saling pengertian antara kedua belah pihak yang terkait dengan keputusan tersebut.
\end{abstract}

Keywords: Decision Making, Organization, Leader.

\section{PENDAHULUAN}

Pada berbagai konteks komunikasi, dikemukakan bahwa tidak ada orang yang tidak terlibat proses komunikasi. Dengan melakukan proses komunikasi, manusia dapat berhubungan satu dengan yang lainnya dalam kehidupan sehari-hari. Jika berada pada konteks komunikasiorganisasi maka sudah dapat diketahui bahwa suatu organisasi hanya dapat terbentuk jika terdapat dua orang atau lebih yang melakukan interaksi dan berkomunikasi dan memiliki tujuan yang sama.

Tujuan dalam organisasi tidak akan tercapai apabila komunikasi yang terjalin hanya dilakukan secara individual. Maka peran kelompok dalam organisasi juga menjadi hal penting demi hasil kerja yang lebih maksimal. Diskusi dalam kelompok dapat menjadi lebih fleksibel dan responsif 
dalam menghadapi suatu masalah karena dalam sebuah kelompok, para karyawan dapat berkumpul, menyebar, memfokuskan diri kemudian bubar dengan cepat (Robbins, 2002, p. 129).

Pelaksanaan kerja yang dilakukan secara kelompok tidak hanya bermanfaat bagi kelancaran pelaksanaan program saja, namun dalam hal pengambilan keputusan. Setiap anggota yang bekerja secara kelompok merupakan perpaduan anggota yang saling membutuhkan dan melengkapi satu sama lainnya. Diskusi kelompok mampu menghasilkan informasi, pandangan dan keputusan yang lebih berkualitas dibandingkan bekerja secara individu. Maka kemudian pemimpin kelompok memiliki peran penting dalam menjaga peserta kelompok dalam membuat keputusan yang efektif bagi semua pihak yang berhubungan dengan pengambilan keputusan.

Tulisan ini bertujuan untuk memberikan deskripsi mengenai dinamika pengambilan keputusan dalam komunikasi organisasi. Dalam tulisan ini dibahas mengenai tujuan komunikasi organisasi, tujuan pengambilan keputusan, aliran informasi serta gaya kepemimpinan dalam pengambilan keputusan yang kemudian akan dianalisis melalui contoh kasus mengenai pemutusan kontrak pembangunan monorel yang dilakukan Ahok, Gubernur DKI Jakarta terhadap PT. Jakarta Monorail. Tulisan ini diharapkan dapat memberikan gambaran mengenai pentingnya penetapan tujuan, perolehan aliran informasi dan gaya kepemimpinan dalam pengambilan keputusan dari sebuah komunikasi organisasi yang tentunya berpengaruh terhadap maksimalitas pencapaian tujuan organisasi.

\section{LANDASAN TEORI}

\section{Corporate Decision Making dalam Komunikasi Organisasi}

Komunikasi dalam sebuah organisasi merupakan salah faktor penting dalam menentukan pembuatan keputusan yang terjadi antar pelaku dalam organisasi.Pace dan Faules (2013. p. 33) mengatakan bahwa komunikasi organisasi merujuk pada suatu makna di mana terdapat pembentukan makna dari sebuah interaksi yang terjadi dalam organisasi.Komunikasi organisasi adalah "perilaku pengorganisasian" yang terjadi dan bagaimana mereka yang terlibat dalam proses itu bertransaksi serta memberi makna atas apa yang sedang terjadi.

Berefleksi pada proseskomunikasi bisnis, dalam sebuah organisasi juga terdapat fungsi dan tujuan sepanjang proses komunikasinya. Priyatna dan Ardianto (2008, p. 24-25) mengemukakan empat fungsi yang dapat pula dilaksanakan dalam konteks komunikasi organisasi, yakni:

1. Informatif

Pimpinan dan anggota organisasi membutuhkan banyak sekali informasi untuk menyelesaikan tugas-tugas mereka. Informasi tersebut berkaitan dengan upaya organisasi untuk mencapai tujuannya.

2. Pengendalian (Regulatory)

Komunikasi berfungsi sebagai pengatur dan pengendali organisasi. Komunikasi dalam hal ini berupa peraturan, prosedur, perintah, dan laporan.

3. Persuasif

Komunikasi berfungsi mengajak orang lain mengikuti atau menjalankan ide/ gagasan atau tugas.

\section{Integratif}

Dengan adanya komunikasi, organisasi yang terbagi menjadibeberapa bagian atau departemen akan tetap merupakan satukesatuan yang utuh dan terpadu.

Sementara itu Curtis, Floyd dan Winsor (2005, p. 6) mengemukakan tujuan dalam komunikasi bisnis yang juga bisa disejajarkan dalam konteks komunikasi organisasi, yaitu:

1. Menyelesaikan Masalah dan Membuat Keputusan

Pendapat tersebut tidak dapat dibantah karena semakin tinggi kedudukan seseorang dalam bisnis, dirinya akan semakin bergantung kepada keahlian seseorang dalam membuat keputusan dan memecahkan masalah untuk suatu 
keberhasilan. Keahlian teknis seringkali lebih penting bagi para manajer tingkat rendah, walaupun tampaknya para manajer tingkat menengah menggunakan keahlian teknis dan konsepsi (dalam pembuatan keputusan strategis) paling sering digunakan para manajer tingkat atas.

2. Mengevaluasi Perilaku

Para anggota organisasi memerlukan suatu penilaianuntuk mengetahui halhal yang akan mereka lakukan ataukapan koreksi terhadap prestasi mereka diperlukan.Penilaian terhadap hal-hal seperti itu memerlukan kepekaandan keahlian komunikasi.

Mengingat bahwa bisnis merupakan sebuah relasi antara dua pihak yang berbeda, tidak puladapatdipungkiridalam komunikasi bisnis dapat pula melibatkan dua organisasi. Maka berdasarkan tujuan komunikasi bisnis yang dinyatakan tadi terlihat bahwa pembuatan keputusan merupakan salah satu faktor yang sangat penting bagi suatu organisasi yang terlibat dalam relasi bisnis untuk mencapai tujuannya.Menurut Davis (1979, p. 5), proses pengambilan keputusan merupakan suatu proses pemilihan alternatif terbaik dari berbagai alternatif yang secara sistematis dipilih sebagai cara untuk menyelesaikan masalah. Keputusan merupakan hasil pemecahan masalah yang dihadapi dengan tegas. Keputusan merupakan suatu jawaban pasti terhadap suatu pertanyaan sehingga keputusan harus mampu menjawab pertanyaan yang menjadi suatu persoalan. Keputusan dapat pula berupa tindakan terhadap pelaksanaan yang sangat menyimpang dari rencana semula.

Organisasi membentuk dasar dari konsep keputusan, begitu yang dikemukakan pada Teori Luhmann. Keputusan dipandang sebagai "pilihan antara alternatif" dan sebagai bentuk komunikasi membatasi kontingensi. Andersen berpendapat bahwa keputusan adalah kesatuan yang membelah dunia serta suatu bentuk komunikasi yang memperhitungkan harapan sosial anggota organisasi. Harapan dari suatu keputusan dapat dibagi dalam tiga kelompok: harapan duniawi yang diarahkan ke masa depan, harapan faktual diarahkan pada organisasi dan harapan masyarakat diarahkan pada pengambilan bagian dalam komunikasi (Mykkänen dan Tampere, 2014).

Keputusan dalam organisasi, merupakan penciptaan harapan sosial dari keputusan berikutnya. Seidl dan Becker (2006, p. 26) melihat keputusan sebagai suatu proses organisasi, yang dibuat ketika salah satu keputusan terhubung ke yang lain,yang pada gilirannya menyebabkan ketidakpastian keputusan pertama yang hilang karena keputusan tersebut tidak lagi dievaluasi. Proses ini dalam organisasi merupakan pusatproses sosialisasi, yang berkaitan pula dengan norma, nilai dan keyakinan organisasi.

Proses ini juga menunjukkan sikap manajerial terhadap komunikasi dan mungkin juga mempengaruhi sikap dan persepsi individual terhadap organisasi. Keputusan juga diakui sebagai hasil dari proses informasi, di mana organisasi dapat dipandang sebagai partikel informasi yang bergerak maju serta akibatnya, dalam konteks komunikasi organisasi, organisasi dapat dianggap sebagai 'otak' atau 'komputer'. Keputusan dasarnya dipandang sebagai fungsi yang bergantung pada penciptaan, manajemen, alirandan penggunaan informasi (Mykkänen dan Tampere, 2014).

Keputusan dalam organisasi juga dapat dipandang sebagai tindakan sosial terkoordinasi. Habermas (dalam Mykkänen dan Tampere, 2014) menemukan fakta bahwa kegiatan antar individu membutuhkan sejumlah komunikasi yang harus dipenuhi untuk mengkoordinasikan tindakan efektif yang bertujuan untuk memuaskan kebutuhan. Dalam organisasi, tindakan pemenuhan kebutuhan ini adalah proses pemecahan masalah yang efektif, dengan kata lain, pengambilan keputusan. Aksi sosial dan praktek komunikatif juga bagian yang melekat dari proses pengambilan keputusan.

Simon (dalam Mykkänen dan Tampere, 2014) mengemukakan organisasi sebagai sistem berorientasi pada tujuan sehingga 
pengambilan keputusan sebagian besar berkaitan dengan suatu pola kegiatan yang efektif yang diarahkan menuju tujuan tertentu. Pengambilan keputusan dilihat sebagai proses berpikir dan pemecahan masalahyang diarahkan pada penemuan dan alternatif dari solusi.Keputusan melibatkan pilihan yang dipilih dari sejumlah alternatif. Final pilihan tentu saja diarahkan tujuan organisasi.

Menurut Hasan (2002: 2), pengambilan keputusan sebagai suatu kelanjutan dari cara pemecahan masalah memiliki fungsi antara lain:

1. Pangkal permulaan dari semua aktivitas manusia yang sadar dan terarah, baik secara individual maupun secara kelompok, baik secara institusional maupun secara organisasional.

2. Sesuatu yang bersifat futuristik, artinya bersangkut paut dengan hari depan, masa yang akan datang, dimana efeknya atau pengaruhnya berlangsung cukup lama.

Sedangkan tujuan dari pengambilan keputusan itu sendiri dapat dibedakan menjadi dua, yaitu:

1. Tujuan yang bersifat tunggal

Tujuan pengambilan keputusan yang bersifat tunggal terjadi apabila keputusan yang dihasilkan hanya menyangkut satu masalah, artinya bahwa sekali diputuskan, tidak ada kaitannya dengan masalah lain.

2. Tujuan yang bersifat ganda

Tujuan pengambilan keputusan yang bersifat ganda terjadi apabila keputusan yang dihasilkan itu menyangkut lebih dari satu masalah, artinya bahwa satu keputusan yang diambil itu sekaligus memecahkan dua masalah (atau lebih), yang bersifat kontradiktif atau yang bersifat tidak kontradiktif (Hasan, 2002: 3).

Feldman dan Maret (dalam Mykkänen dan Tampere, 2014) berteori tentang bagaimana organisasi menggunakan informasi dalam proses pembuatan keputusan. Meskipun informasi adalah bantuan untuk membuat pilihan, tetapi juga dapat menciptakan stres bagi pembuat keputusan. Organisasi membuat keputusan eksplisit dan implisit tentang mencari danmenggunakan informasi, yang dapat meningkatkan perkiraan konsekuensi dan referensi tentang masa depan. Keputusan didasarkan pada perkiraan manfaat yang diharapkan tetapi nilai informasi tergantung pada relevansinya terhadap keputusan sebelum dibuat. Informasi memiliki nilai hanya jika dapat diharapkan dapat mempengaruhi pilihan yang ada dalam pembuatan keputusan. Jadi komunikasi merupakan dasar dalam melakukan proses pengambilan keputusan yang bertujuan mengukur efektivitas dari sebuah keputusan.

Dalam sebuah proses pengambilan keputusan yang efektif, perspektif fungsional juga dikemukakan oleh Hirokawa dan Gouran dalam teorinya mengenai proses diskusi untuk mengambil keputusan. Perspektif ini bermula dari adanya keraguan mengenai peran dari diskusi kelompok yang kemudian diperbesar dengan kritikan dari para anggota kelompok yang sering berkomentar sinis ketika diskusi selesai.Mereka merasa bahwa diskusi kelompok hanya membuang-buang waktu dan tenaga serta sebaiknya dapat dilakukan secara individu saja.Hirokawa dan Gouran tidak menyetujui alasan ini, karena mereka merasa bahwa interaksi kelompok memiliki efek positif dalam pengambilan keputusan akhir. Pada teorinya, Hirokawa da Gouran menekankan bahwa pada proses pengambilan keputusan, diskusi antara pihak-pihak terkait dengan memperhatikan empat fungsi yang ia kemukakan dalam teorinya akan menghasilkan keputusan terbaik dan menciptakan komitmen yang akan dijalankan oleh seluruh pihak untuk mencapat tujuan bersama.

Menurut Hirokawa dan Gouran (dalam Griffin, 2003: 232), proses pengambilan keputusan kelompok diperlukan untuk memenuhi empat fungsi agar anggota kelompok merasakan hasil pengambilan keputusan yang berkualitas. Perspektif fungsional ini menggambarkan dan mengilustrasikan kebijaksanaan dalam interaksi bersama.Tujuan akhir mereka untuk menawarkan nasehat praktis bagaimana 
partisipan dapat bertindak untuk menjamin keputusan kelompok yang terbaik.Interaksi kelompok memiliki dampak yang positif dalam keputusan akhir.

Hirokawa dan Gouran melihat proses pengambilan keputusan sebagai kebutuhan untuk memenuhi empat syarat fungsi jika anggota kelompok ingin mencapai solusi kualitasyang tinggi. Kondisi ini sebagai syarat untuk fungsi pengambilan keputusan yang efektif. Hubungan antara keempat fungsi tersebut dapat digambarkan sebagaimana gambar 1 .

Menurut perspektif fungsional, empat tugas atau fungsi tersebut antara lain:

\section{a. Analysis of the Problem (Analisis Masalah)}

Proses pengambilan keputusan biasanya dimulai dengan mengidentifikasikan dan menilai suatu masalah. Pada tahap ini mereka harus menjawab berbagai pertanyaan terhadap situasi yang sedang dihadapi. Anggota-anggota kelompok dalam sebuah organisasi harus berpikir realistis dalam melihat kondisi yang sedang terjadi sekarang ini jika suatu perbaikan atau perubahan perlu terjadi dalam sebuah perusahaan (Morissan, 2009, p. 141).

Suatu masalah terjadiapabilapencapaian organisasi tidak memenuhi sasaran yang ditetapkan (Griffin, 2003, p. 233).Sebuah masalah (problem) merupakan perbedaan antara realitas dengan harapan dari organisasi tersebut. Adanya perbedaan antara keadaan yang sesungguhnya dan keinginan yang ditetapkan tidaklah menjamin bahwa akan membuat keputusan yang tepat guna menyelesaikan masalah. Maka kemudian terdapat tiga hal yang harus dilihat, yakni menyadariadanyaperbedaan, adanyamotivasi untuk mengurangi perbedaan tersebut serta faktor pengetahuan, kemampuan dan sumber daya yang diperlukan untuk menyelesaikan masalah tersebut (Griffin, 2003, p. 233).

\section{b. Goal Setting (Penetapan Tujuan)}

Langkah selanjutnya setelah mengumpulkan dan mengevaluasi informasi terkait dengan masalah yang dihadapi, kelompok perlu menetapkan tujuan yang disepakati agar identifikasi masalah yang ada dapat diselesaikan dengan solusi yang tepat. Hal ini dilakukan karena anggota-anggota di dalam kelompok membutuhkan penjelasan mengenai pekerjaan yang akan dikerjakan (Morissan, 2009. p. 142).

Hirokawa dan Gouran (dalam Griffin, 2003, p. 234) menghormati tujuan diskusi dan bersikap obyektif sebagai syarat penting dari fungsi pengambilan keputusan.Kebutuhan kelompok adalah menetapkan standar untuk mempertimbangkan solusi-solusi perubahan dalam organisasi.

\section{Gambar 1. Jalur Pengambilan Keputusan menurut Functional Perspective}

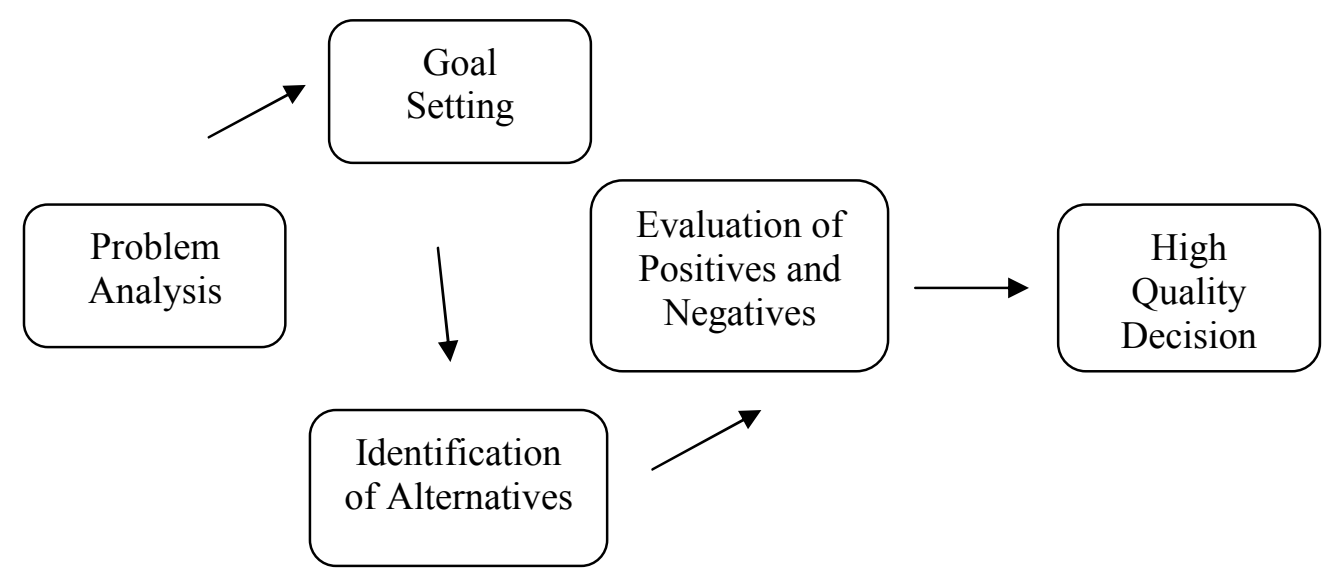

Sumber : Griffin, 2003, p. 232 


\section{c. Identification of Alternatives (Identifikasi terhadap Berbagai Alternatif yang Ada)}

Pada tahap ini, Hirokawa dan Gouran (dalam Morissan, 2009, p. 143) menekankan pentingnya memiliki sejumlah alternatif solusi ketika kelompok mengambil keputusan terhadap masalah yang sedang dihadapi bersama.Kelompok kemudian menyusun berbagai usulan dari para anggotanya mengenai solusi-solusi alternatif dari permasalahan yang ada.

Pada tahap ini, banyak informasi dikumpulkan, data analisa, dan kemudian dirundingkan kemungkinanalternatif tindakan untuk diidentifikasikan. Keterlibatan orang lain sangat penting untuk memaksimumkan informasi dan menciptakan komitmen. Karena adanya sejumlah informasi yang diperlukan dan dikumpulkan sehingga membuat langkah ini memakan waktu yang cukup lama daripada langkah yang lain dalam proses pengambilan keputusan (Griffin, 2003, p. 235).

Dalam pernyataan mengenai fungsional perspektif, Hirokawa dan Gouran (dalam Griffin, 2003, p. 235) menitikberatkan pada penyusunan angka-angka alternatif solusi yang mana anggota-anggota dalam kelompok dapat memilihnya.Jika tidak ada satupun orang yang memperhatikan kebutuhannya untuk menghasilkan banyak alternatifalternatif sebagai kemungkinan yang sangat realistis, maka kemungkinan penemuan surat-surat dapat diterima.

\section{d. Evaluation of Positives and Negatives Characteristic}

Berbagai solusi alternatif yang tersedia kemudian dievaluasi dengan tujuan akhirnya adalah untuk mengambil keputusan.Anggota kelompok harus menguji keunggulan dari setiap pilihan yang tersedia untuk menentukan pilihan solusi yang paling memenuhi kriteria yang dinilai penting (Morissan, 2009, p. 144).

Hirokawa dan Gouran (dalam Griffin, 2003, p. 236) memperingatkan kelompokkelompok lemah dan sering membutuhkan satu anggota untuk mempertimbangkan positifdan negatif darialternatifyang lainnya. Pilihan-pilihan dari solusi adalah seleksi yang paling menjanjikan dari beberapaalternatif tindakan.Alternatif terbaik menyediakan solusi yang terbaik sesuai dengan sasaran serta mencapai hasilyang diharapkan. Karena jumlah resiko melekat pada setiap keputusan sehingga harus diperkirakan keberhasilannya dan memilih alternatif dengan tingkat resiko paling sedikit (Griffin, 2003: 236).

Menurut Hirokawa dan Gouran (Griffin, 2003: 237), dalam pengambilan keputusan kelompok terdapat tiga jenis komunikasi, yaitu:

1. Promotive, merupakan interaksi yang menggerakkan kelompok sesuai dengan tujuan organisasi.

2. Disruptive, interaksi yang mengalihkan, memperlambat atau menghambat, atau menghalangi anggota kelompok dalam melaksanakan empat fungsi tugas.

3. Counteractive, yaitu interaksi yang digunakan oleh anggota kelompok untuk mengembalikan kelompok pada tujuan awal.

Ketika berbagai individumelakukan proses komunikasi dan bekerjasama dalam sebuah kelompok dalam organisasi, individu cenderung untuk mengambil nilai-nilai inti dari kelompok. Individu dalam kelompok sering melakukan kompromi dari nilainilai mereka sendiri demi yang dimiliki oleh kelompok.Nilai melibatkan emosi, pengetahuan, pikiran, dan akhirnya pilihan respon. Nilai bervariasi antara individu dan karena nilai-nilai mengatur perilaku, mereka mewarnai pandangan cara individu dan menanggapi dunia mereka. Hal ini penting untuk memahami nilai-nilai terhadap pilihan dalam proses pembuatan keputusan. Sementara nilai-nilai yang didapat dan dilakukan, berubah dari waktu kewaktu, serta mewakili komponenpenting dari kepribadian dari anggota kelompok.Umumnya hal ini digambarkan sebagai standar sosial yang normal, atau norma-norma, serta nilai-nilai yang dapat mempengaruhi bagaimana orang 
membuat pilihan (Chmielewski, 2004).

Nilai-nilai yang dimiliki individu dalam kelompok serta nilai-nilai yang dipegang kelompok dalam suatu organisasi memengaruhi cara mereka dalam mencari alternatif solusi dari masalah yang sedang dihadapisehingga berpengaruhjugaterhadap keputusan yang dibuat oleh kelompok itu sendiri. Maka dari itu, pemimpin diskusi dalam kelompok memiliki peranan penting dalam menjaga ide-ide dan inovasi anggota dalam memberikan solusi sehingga pengambilan keputusan yang dilakukan oleh pemimpin diskusi memiliki kualitas yang tinggi.

Faktor penting yang kemudian juga memengaruhi pembuatan keputusan suatu kelompok dalam organisasi adalah gaya partisipasi pemimpin dalam kelompok tersebut. Gaya ini kemudian dibedakan menjadi tiga, yaitu gaya pengambilan keputusan yang otoritarian, laissez-faire dan partisipatif. Ketiga gaya tersebut tentunya akan menciptakan level partisipasi yang berbeda-beda di antara para anggotanya (O’Hair et al, 2009: 361).

Gaya yang pertama adalah gaya pengambilan keputusan secara otoritarian, di mana seorang pimpinan mengambil keputusan untuk kelompok. Partisipan tidak dilibatkan dalam membuat keputusan; mereka hanya melakukan apa yang disuruh pimpinan. Ada dua situasi yang membutuhkan gaya pengambilan keputusan secara otoritarian, yakni saat krisis dan adanya kondisi kurangnya pengetahuan (informasi). Ketika sebuah kelompok menghadapi krisis, keputusan harus diambil dengan cepat dan tidak banyak waktu untuk diskusi. Ketika anggota diminta untuk memberi opini, bukti atau detail material di mana mereka tidak memiliki banyak informasi atau pengetahuan yang dibutuhkan, maka waktu dan tenaga akan terbuang sia-sia. Maka dalam kasus ini gaya yang paling cocok adalah otoritarian (O'Hair et al, 2009: 361).

Namun gaya ini memiliki kelemahan, yakni menurunkan moral partisipan yang ingin berkontribusi tapi tidak diizinkan. Gaya ini melemahkan rasa percaya kepada pimpinan dan menimbulkan kecurigaan terhadap niat pimpinan. Peluang terjadinya keputusan yang buruk adalah tinggi karena beberapa masukan berharga mungkin tidak pernah muncul dan ide-ide tetap tidak dibahas (O'Hair et al, 2009: 361).

Gaya pengambilan keputusan yang kedua adalah gaya keputusan laissez-faire. Gaya keputusan laissez-faire adalah gaya di mana hanya ada sedikit keterlibatan pimpinan kelompok. Anggota kelompok yang beroperasi dengan tipe keputusan ini pada dasarnya membuat keputusan tanpa pedoman atau arahan dari pimpinan. Kelompok kemudian berusaha memutuskan sendiri. Tipe ini sulit ditangani karena beberapa orang mungkin merasa berhak menjadi pimpinan tanpa menunjukkan keterampilan yang mencukupi. Kelompok laissez-faire mungkin akan bertele-tele dalam mengidentifikasi masalah atau mengambil keputusan kecuali para anggotanya bersatu padu (O'Hair et al, 2009: 362).

Gaya pengambilan keputusan yang ketiga adalah gaya pengambilan keputusan partisipatif yang merujuk pada gaya manajemen atau tipe prosedur pengambilan keputusan yang dengannya bawahan diizinkan memengaruhi beberapa keputusan manajer. Dalam gaya keputusan partisipatif, pimpinan membuat keputusan bersama kelompok (O'Hair et al, 2009: 363).

Riset mengindikasikan bahwa pengambilan keputusan partisipatif memberi banyak keuntungan bagi anggota. Anggota kelompok yang berpartisipasi dalam pengambilan keputusan akan lebih memiliki komitmen pada hasil keputusan ketimbang anggota yang tidak ikut serta. Partisipasi juga menghasilkan pengalaman yang menarik dan memuaskan bagi anggota kelompok. Selain itu, kualitas keputusan meningkat apabila anggota kelompok yang memiliki keahlian atau pengetahuan yang tidak dipunyai pimpinan bersedia diajak kerja sama (O'Hair et al, 2009:363).

Dalam pengambilan keputusan, terdapat berbagai cara dan gaya yang dilakukan sebuah organisasi. Berbagai gaya dan cara ini dapat dilakukan oleh seluruh anggota 
organisasi maupun pemimpin organisasi tersebut. Pengambilan keputusan baik secara keseluruhan organisasi maupun hanya lewat pemimpin memiliki pengaruh dalam keputusan itu sendiri.Berbagai pihak yang terkait dalam pengambilan keputusan dan ikut dalam diskusi dalam rangka pemecahan masalah diharapkan dapat melaksanakan setiap keputusan yang telah diambil dan disepakati bersama.Kehadiran pihak terkait ini menjadi penting karena dengan demikian sebuah masalahdapatdilihatdariberbagai sisi dan keputusan yang diambil tidak merugikan salah satu atau kedua pihak.Kesepakatan dalamorganisasidan pengambilan keputusan diharapkan merupakan keputusan terbaik demi terwujudnya tujuan bersama.

\section{HASIL DAN PEMBAHASAN}

\section{Gaya Ahok dalam Pengambilan Keputusan}

Penjelasanteorimengenaigayapartisipasi pemimpin dalam pembuatan keputusan tadi telah memperlihatkan bahwa pemimpin memiliki andil penting dalam proses pembuatan keputusan dalam organisasi. Kepemimpinan yang efektif dapat menjadi sangat penting untuk mencapai konsensus dan menentukan kualitas dari keputusan yang diambil.Maka keputusan pemimpin menjadi sebuah tolak ukur penting yang kemudian berpengaruh pada komunikasi yang dijalankan antara pemimpin dalam sebuah organisasi maupun terkait dengan organisasi lain.

Gaya partisipasi pemimpin yang khas dan berpengaruh pada sebuah organisasi juga diperlihatkan Basuki Tjahaja Purnama, alias Ahok sebagai Gubernur DKI Jakarta dalam melakukan keputusan bisnis bersama PT.Jakarta Monorail (PT JM). Ahok pada tanggal 9 Januari 2015, secara mengejutkan memastikan bahwa pihaknya akhirnya akan memutus kontrak pembangunan modal transportasi monorel dengan PT Jakarta Monorail. Keputusan ini diambilnya setelah pada tanggal yang sama beliau sengaja menemui Presiden Joko Widodo di Istana Kepresidenan. Ahok menuturkan, penolakan kali ini berdasarkan kepada kajian terhadap dokumen teknis yang diberikan oleh PT JM kepada Pemprov DKI pada Oktober 2014. Kajian kali ini dilakukan secara langsung oleh Kementerian Pekerjaan Umum (Laskito dan Mukti, 2015).

Berdasarkan kajian itu, Ahok mengatakan, pemerintah pusat menganggap pembangunan depo (tempat penyimpanan gerbong) monorel di atas Waduk Setiabudi, seperti yang PT JM tuliskan di dokumen teknisnya, merupakan sesuatu yang sangat rawan terhadap keamanan tanggul Latuharhari. Bila dipaksakan, kata Ahok, bukan tidak mungkin pembangunan depo itu malah akan menimbulkan banjir di Jalan MH Thamrin dan Jenderal Sudirman pada Januari 2013 lalu. (Laskito dan Mukti, 2015).

Namun keputusan Ahok tersebut ternyata tidak diketahui oleh pihak PT.JM. pihak PT JM bahkan belum menerima surat resmi dari Pemprov DKI mengenai keputusan resmi dihentikan atau dilanjutkan pembangunan monorail tersebut. Direktur PT Jakarta Monorail (PT JM) Sukmawati Syukur bahkan mengaku belum pernah melakukan pembicaraan langsung bersama Gubernur DKI Jakarta Basuki Tjahaja Purnama (Ahok), terutama membicarakan perihal keberlanjutan proyek pembangunan monorel di ibu kota. Jadi Sukmawati Syukur mengatakan bahwa Pak Ahok tidak pernah rapat langsung dengan PT JM. Hal ini membuat informasi yang didapat PT.JM mengenai keputusan Ahok tidak pernah lengkap (Aziza, 2015).

Berangkat dari dua pihak yang berkepentingan di atas, antara Ahok dan PT JM, hal ini dapat dianalisis dengan berefleksi pada pengertian bisnis menurut Brennan (dalam Priyatna dan Ardianto, 2008: 24-25) sebagai "a dinamic structureof interchanging ideas, feelings and cooperative effortsto get profit." (suatu struktur yang dinamis dari pertukaran gagasan, perasaan dan usaha bersama untuk mendapatkan keuntungan). Merujuk pengertian tersebut, maka hubungan dijalankan oleh PT.JM dan pemerintah propinsi DKI Jakarta yang dipimpin oleh Ahok merupakan hubungan 
bisnis, karena adanya bentuk kerja sama di antaranya kedua demi mencapai tujuan tertentu, yakni terciptanya monorail sebagai salah satu transportasi bagi warga DKI Jakarta.

Sementara itu jika dikaji menurut tujuan komunikasi antara Ahok dan PT JM, hubungan komunikasi yang dijalankan oleh Ahok dan PT. Jakarta Monorail memiliki tujuan untuk menyelesaikan masalah dan membuat keputusan. Pembuatan keputusan dilakukan dalam rangka mewujudkan keinginan pemerintah propinsi DKI Jakarta sendiri untuk membangun monorail yang diperuntukkan untuk kemudahan warga DKI Jakarta.

Berdasarkan tujuan komunikasi yang dilakukan oleh pihak Ahok dan PT.Jakarta Monorail dapat terlihat bahwa pembuatan keputusan merupakan salah satu faktor yang diperlukan dalam pencapaian tujuan hubungan yang dilakukan oleh keduanya. Proses pengambilan keputusan merupakan suatu proses pemilihan alternatif terbaik dari berbagai alternatif yang secara sistematis dipilih sebagai cara untuk menyelesaikan masalah. Keputusan merupakan hasil pemecahan masalah yang dihadapi dengan tegas.Keputusan merupakan suatu jawaban pasti terhadap suatu pertanyaan sehingga keputusan harus mampu menjawab pertanyaan yang menjadi suatu persoalan. Keputusan dapat pula berupa tindakan terhadap pelaksanaan yang sangat menyimpang dari rencana semula (Davis, 1979: 5).

Keputusan yang diambil Ahok dalam memutuskan proyek pembangunan monorel Jakarta merupakan suatu tindakan yang merupakan reaksi terhadap suatu persoalan bahkan suatu pelaksanaan yang sangat menyimpang dari rencana semula. Keputusan Ahokuntuk menghentikan proyek pembangunan monorel bukannya tanpa alasan.Ahok menuturkan, penolakannya terhadap pembangunan monorel ini berdasarkan kepada kajian terhadap dokumen teknis yang diberikan oleh PT JM kepada Pemprov DKI pada Oktober 2014 yang dilakukan secara langsung oleh Kementerian
Pekerjaan Umum. Berdasarkan kajian tersebut, pemerintah pusat menganggap pembangunan depo (tempat penyimpanan gerbong) monorel di atas Waduk Setiabudi, seperti yang PT JM tuliskan di dokumen teknisnya, merupakan sesuatu yang sangat rawan terhadap keamanan tanggul Latuharhari. Bila dipaksakan, kata Ahok, bukan tidak mungkin pembangunan depo itu malah akan menimbulkan banjir di Jalan MH Thamrin dan Jenderal Sudirman pada Januari 2013 lalu. (Laskito dan Mukti, 2015).

Maka kemudian keputusan Ahok yang akhirnya menghentikan kontrak terhadap proyek pembangunan monorel tersebut dapat dipandang sebagai reaksinya terhadap akibat yang dapat ditimbulkan dari pembangunan monorel tersebut serta tujuannya dalam membuat keputusan, yakni memiliki tujuan yang bersifat ganda.Tujuan pengambilan keputusan yang bersifat ganda terjadi apabila keputusan yang dihasilkan itu menyangkut lebih dari satu masalah, artinya bahwa satu keputusan yang diambil itu sekaligus memecahkan dua masalah (atau lebih), yang bersifat kontradiktif atau yang bersifat tidak kontradiktif (Hasan, 2002: 3).Ahok memandang bahwa proyek monorek tersebut ternyata tidak hanya rawan terhadap keamanan tanggul, tetapi juga dapat menyebabkan banjir.Ahok tidak ingin suatu proyek yang bertujuan untuk keuntungan warga malah menimbulkan masalah baru bagi para warga Jakarta.

Dalam pembuatan keputusan ini dapat terlihat pula bahwa keputusan Ahok menolak proyek pembangunan monorel mepertimbangkan harapan sosial dari luar organisasi, yakni pendapat Presiden RI Joko Widodo dan tentunya warga Jakarta. Harapan dari suatu keputusanyang dibuat Ahok kemudian mengarah pada harapan duniawi yang diarahkan ke masa depan,serta harapan masyarakat diarahkan pada pengambilan bagian dalam komunikasi.

Pertimbangan terhadap harapan yang dilakukan Ahok sebelum mengambil keputusanmenunjukkanbahwaPengambilan keputusan yang dilakukan Ahok dapat pula dikatakan sebagai sebuah output dari proses 
pertimbangan segala informasi yang beliau peroleh mengenai pembangunan tersebut. Menurut teori, keputusan juga diakui sebagai hasil dari proses informasi, di mana organisasi dapat dipandang sebagai partikel informasi yang bergerak maju serta akibatnya, dalam konteks komunikasi organisasi,organisasi dapat dianggap sebagai 'otak' atau 'komputer' (Mykkänen dan Tampere, 2014).

Organisasi membuat keputusan eksplisit dan implisit tentang mencari danmenggunakan informasi, yang dapat meningkatkan perkiraan konsekuensi dan referensi tentang masa depan. Informasi memiliki nilai hanya jika dapat diharapkan dapat mempengaruhi pilihan yang ada dalam pembuatan keputusan (Mykkänen dan Tampere, 2014).Dari teori ini maka jelas terlihat bahwa keputusan yang diambil Ahok berkenaan dengan proyek pembangunan monorel diambil dari beberapa informasi dan referensi yang diperolehnya sebelum mengambil keputusan.

Referensi informasi pertama tentunya berdasarkan kajian terhadap dokumen teknis yang diberikan oleh PT JM kepada Pemprov DKI pada Oktober 2014 yang dilakukan secara langsung oleh Kementerian Pekerjaan Umum.Setelah itu, beliau sengaja menemui Presiden Joko Widodo di Istana Kepresidenan untuk membicarakan kajian tersebut.Referensi informasi terakhir yang dirasa paling penting untuk Ahok adalah kajian bahwa pembangunan proyek yang justru dapat merugikan warga Jakarta.Ahok akhirnya menggunakan semua referensi informasinya untuk membuat keputusan terhadap kelanjutan proyek pembangunan monorel oleh PT.Jakarta Monorail.Meskipun beliau tidak melakukan komunikasi intens dengan pihak PT. Jakarta Monorail, tapi di sini, Ahok menganggap warga Jakarta sebagai nilai penting yang berpengaruh besar dalam pengambilan keputusan yang dibuatnya.

Selain dipandang sebagai sebuah hasil dari proses informasi, Seidl dan Becker (2006, p. 26) juga melihat keputusan itu sendiri sebagai suatu proses organisasi, yang merupakan pusat proses sosialisasi dan berkaitan dengannorma,nilai serta keyakinan organisasi.Nilai melibatkan emosi, pengetahuan, pikiran, dan akhirnya pilihan respon dari individu. Nilai bervariasi antara individu dan karena nilai-nilai mengatur perilaku, mereka mewarnai pandangan cara individu dan menanggapi dunia mereka (Chmielewski, 2004).

Jika dihubungkan dengan keputusan yang dibuat Ahok, terlihat bahwa Ahok sebagai pemimpin organisasi dan pihak yang memiliki hak penuh dalam pembuatan keputusan melibatkan nilai-nilai yang ada pada dirinya untuk membuat keputusan. Pengetahuan dan referensi informasi yang beliau peroleh dari Jokowi, Kajian Kementrian Pekerjaan Umum serta pemikirannya terhadapkesejahteraanwarga Jakarta menjadi pedoman dasar pemikirannya untuk akhirnya memutuskan kontrak proyek pembangunan monorel. Ahok yang terkenal dengan sikap lurus dan keras serta ketegasannya dalam memimpin berpengaruh pula terhadap cara beliau memperlakukan PT.Jakarta Monorel.

Ahok yang menganggap warga Jakarta sebagai nilai paling penting dari setiap pekerjaan yang beliau lakukan membuat beliau mengesampingkan peran PT. Jakarta Monorel dalam memberikan referensi pendapat mengenai proyek tersebut. Alhasil, karena dianggap proyek tersebut merugikan warga Jakarta, Ahok kemudian memutuskan kontrak proyek pembangunan monorel tanpa diketahui oleh pihak PT.Jakarta Monorail sendiri sebagai pihak yang diajak kerja sama oleh Ahok. Pihak PT JM bahkan mengatakan (dalam Aziza, 2015) bahwa pihaknya belum menerima surat resmi dari Pemprov DKI mengenai keputusan resmi dihentikan atau dilanjutkan pembangunan monorel tersebut. Direktur PT Jakarta Monorail (PT JM) Sukmawati Syukur bahkan mengaku belum pernah melakukan pembicaraan langsung bersama Gubernur DKI Jakarta Basuki Tjahaja Purnama (Ahok), terutama membicarakan perihal keberlanjutan proyek pembangunan monorel di ibu kota.

Cara Ahok memutuskan kontrak proyek pembangunan monorel tanpa sepengetahuan PT.Jakarta Monorail merupakan kekurangan yang dilakukan oleh Ahok dalam membuat 
keputusan. Meski Ahok dianggap sebagai pihak yang membuat keputusan dan tujuan Ahok demi kebaikan, yang adalah demi keamanan warga Jakarta, namun tidak melakukan komunikasi secara personal dengan pihak yang diajak kerja sama secara bisnis dianggap kurang tepat karena tidak adanya informasi langsung yang diterima PT. Jakarta Monorail mengenai keputusan Ahok tersebut berpengaruh pada kejelasan kelanjutan proyek pembangunan monorel. KeputusansepihakyangdilakukanAhoktanpa diketahui PT.JM tersebut mengakibatkan nasib proyek monorel tersebut menjadi tidak jelas akan diputuskan atau tidak. Belum adanya diskusi yang terjadi antara keduanya membuat PT.JM menjadi bingung dan proyek tersebut menjadi tersendat serta kabur.

Pada teorinya tentang pengambilan keputusan, Hirokawa dan Gouran mengemukakan bahwa dengan berdiskusi antara pihak-pihak yang memiliki kepentingan, dengan memperhatikan antara empat fungsi yang seharusnya berjalan dalam diskusi sehingga keputusan yang dihasilkan adalah keputusan yang dianggap terbaik dan dilaksanakan oleh seluruh pihak yang berkepentingan dan sepakat dengan keputusan tersebut. Pada kasus ini, diskusi antara Ahok dan PT JM tidak berjalan sehingga keputusan yang diambil adalah keputusan berdasarkan pertimbangan satu pihak saja yakni pihak Ahok.

Menganalisis proses pengambilan keputusan yang dilakukan oleh Ahok, merujuk pada Hirokawa dan Gouran (dalam Griffin, 2003: 232) dimana proses pengambilan keputusan kelompok diperlukan untuk memenuhi empat fungsi agar anggota kelompok merasakan hasil pengambilan keputusan yang berkualitas. Fungsional perspektif ini menggambarkan dan mengilustrasikan kebijaksanaan dalam interaksi bersama.

Tujuan akhir mereka untuk menawarkan nasehat praktis bagaimana partisipan dapat bertindak untuk menjamin keputusan kelompok yang terbaik.Interaksi kelompok memiliki dampak yang positif dalam keputusan akhir (Griffin, 2003: 232). Pada teori Perspektif Fungsional dalam
Pengambilan Keputusan, Hirokawa dan Gouran juga mengemukakan empat fungsi dalam proses pengambilan keputusan. Empat fungsi tersebut sekaligus merupakan alur dalam proses pengambilan keputusan yang dilakukan pada sebuah organisasi, yakni: (1) analisis masalah, (2) penetapan tujuan, (3) identifikasi solusi alternatif dan (4) Evaluasi pada positif dan negatif dari alternatif.

Empat fungsi ini berfungsi untuk menghasilkan keputusan terbaik untuk organisasi tersebut. Merujuk pada kasus ini, Ahok sebagai gubernur DKI telah melakukan fungsi pertama dari proses pengambilan keputusan yakni identifikasi masalah. Identifikasi masalah dilakukan dengan melakukan analisa atas dokumen teknis yang diajukan dimana kemudian masalah baru ditemukan yakni pembangunan depo yang dapat mengakibatkan banjir di daerah Thamrin. Dari keempat fungsi yang dikemukakan oleh Hirokawa dan Gouran, ketiga fungsi yang lain seperti penetapan tujuan, alternatif solusi dan evaluasi kurang mendapat tempat.

Merujuk pada empat fungsi yang dikemukakan oleh Hirokawa dan Gouran, pengambilan keputusan secara sepihak tanpa diskusi untuk menetapkan tujuan bersama di antara kedua belah pihak, menetapkan tujuan bersama, mencari alternatif solusi serta melakukan evaluasi demi terciptanya komitmen serta penetapan tujuan yang sama tidak dijalankan dalam proses pengambilan keputusan yang dilakukan oleh Ahok.

Griffin (2003: 233) mengemukakan bahwa terdapat tiga hal yang harus dilihat dalam proses pengambilan keputusan, yakni menyadari adanya perbedaan antara realitas dan harapan, motivasi untuk mengurangi perbedaan tersebut serta faktor pengetahuan, kemampuan dan sumber daya yang diperlukan untuk menyelesaikan masalah tersebut. Pada kasus berhentinya pembangunan monorail ini Ahok telah menyadari adanya perbedaan antara harapan untuk membangun sarana transportasi tetapi pada kenyataannya pembangunan depo dapat menimbulkan masalah baru. Faktor lain seperti kajian pada dokumen teknis yang 
dilakukan pada kasus ini menjadi sumber daya dan sumber pengetahuan dalam proses pengambilan keputusan.

Di sisi lain, tidak dilakukannya diskusi antara Ahok dan pihak PT JM yang menyebabkan pihak PT JM tidak mendapatkan informasi lengkap mengenai proyek ini merupakan salah satu bukti kurangnya motivasi untuk mengurangi perbedaan yang ada. Hirokawa dan Gouran (Griffin, 2003: 237) dalam pengambilan keputusan kelompok terdapat tiga jenis komunikasi.Diantara ketiganya, Ahok sendiri menjalankan jenis komunikasi kedua yakni disruptive yang merupakan jenis komunikasi yang sifatnya memperlambat bahkan menghambat berjalannya keempat fungsi dalam pengambilan keputusan di antara pihak-pihak yang berkomunikasi.

Keadaan yang terjadi antara Ahok dan PT. Jakarta Monorail juga memperlihatkan sisi lain yang dapat dianalisis dari kasus ini, yakni pentingnya gaya partisipasi pemimpin yang berpengaruh terhadap proses pengambilan keputusan. Jika dianalisis dari gaya partisipasinya, gaya Ahok sebagai pemimpin dalam membuat keputusan masuk ke dalam gaya pengambilan keputusan secara otoritarian.

Gaya otoritarian merupakan gaya pengambilan keputusan di mana seorang pimpinan mengambil keputusan untuk kelompokataukomunikasibisnisyangsedang terjalin. Partisipan tidak dilibatkan dalam membuat keputusan dan hanya melakukan apa yang disuruh pimpinan. Ada dua situasi yang membutuhkan gaya pengambilan keputusan secara otoritarian, yakni saat krisis dan adanya kondisi kurangnya pengetahuan (informasi).

Ahok menggunakan gaya otoritarian dalam membuat keputusan mengenai pembangunan monorel kemungkinan dikarenakan Ahok merasa kurangnya informasi yang dimiliki oleh partisipan lain selain dirinya, yakni PT.JM dalam melihat akibat yang dapat ditimbulkan dari adanya pembangunan monorel tersebut. Ahok menganggap partisipan hanya melihat hubungan yang terjalin sebagai sebuah komunikasi bisnis demi keuntungan bisnis semata, sehingga Ahok merasa PT.JM tidak akan memikirkan warga Jakarta sedalam pemikirannya sebagai orang no.1 di ibukota saat ini. Inilah yang membuat Ahok mengambil keputusan sepihak dan memilih gaya otoritarian dalam pengambilan keputusan yang dilakukan.

Namun gaya otoritarian memiliki kelemahan, yakni menurunkan moral partisipan yang ingin berkontribusi tapi tidak diizinkan. Gaya ini melemahkan rasa percaya kepada pimpinan dan menimbulkan kecurigaan terhadap niat pimpinan. Peluang terjadinya keputusan yang buruk adalah tinggi karena beberapa masukan berharga mungkin tidak pernah muncul dan ideide tetap tidak dibahas (O'Hair et al, 2009: 361). Ahok memang dikenal sangat keras dan tegas dalam membuat suatu keputusan. Jika hubungan dengan bisnis, keputusan Ahok mengenai proyek monorel ini dirasa sepihak dan menimbulkan kebingungan dari pihak PT.JM. Keputusan sepihak yang dilakukan Ahok tanpa diketahui PT.JM tersebut mengakibatkan nasib proyek monorel tersebut menjadi tidak jelas akan diputuskan atau tidak. Belum adanya diskusi yang terjadi antara keduanya membuat PT.JM menjadi bingung dan proyek tersebut menjadi tersendat serta kabur.

Ahok memang telah menemukan masalah bahkan akibat jika proyek tersebut dilanjutkan.Melalui penemuan masalah tersebut, Ahok kemudian mengambil solusi dan membuat keputusan untuk segera memutuskan proyek monorel tersebut dikarenakan demi kebaikan warga DKI Jakarta.Namun terlepas dari persoalan politik atau ekonomi yang terjadi di antara kedua belah pihak, keputusan Ahok yang disebabkan karena ketidaksetujuannya mengenai kelanjutan proyek tersebut baiknya dapat didiskusikan langsung dengan pihak PT.JM.Referensi informasi yang diperoleh Ahok dan tujuan utama Ahok dalam membuat monorel hendaknya dapat didiskusikan terlebih dahulu dengan pihak PT.JM agar komunikasi antara keduanya dapat terjalin baik dan tidak 
terjadi kesalahpahaman sehingga kelanjutan proyek monorel tersebut dapat menemukan titik terang serta mampu memberikan solusi terbaik bagi kedua belah pihak yang berdiskusi.

\section{SIMPULAN}

Gaya Ahok dalam mengimplementasikan proses pengambilan keputusan berkenaan dengan kelanjutan proyek pembangunan monorel dengan PT. Jakarta Monorail merupakan contoh di mana segala keputusan yang diambil pemimpin memiliki pengaruh yang besar terhadap komunikasi bisnis yang terjalin antar kedua pihak yang melakukan hubungan bisnis. Apapun gayapartisipasi yang dimiliki pemimpin dalam mengambil keputusan kemudian dikembalikan lagi pada tujuan, informasi yang diperoleh serta kondisi yang sedang terjadi.

Apapun gaya partisipasi pengambilan keputusan menjadi tepat ketika pemimpin benar-benar juga memikirkan tujuan yang paling tepat dari suatu proses pengambilan keputusan, memperhatikan betul referensi informasi yang diperoleh secara komprehensif serta mempertimbangkan kondisi yang terjadi sebelum mengambil suatu keputusan. Ketiga hal ini diperlukan agar gaya partisipasi dapat dipilih secara tepat sehingga keputusan yang diambil tidak menimbulkan kesalahpahaman, melainkan dapat memberikan manfaat bagi kedua belah pihak yang melakukan proses komunikasi secara bisnis.

Proses pembuatan keputusan yang merupakan suatu kondisi penting demi pencapaian tujuan organisasi tentunya tidak hanya menitikberatkan tanggung jawab pada pemimpin. Selain pemimpin, semua pihak yang berkaitan dengan proses pembuatan keputusan seharusnya juga memiliki peran dan tanggung jawabyang sama-sama penting dalam rangka menghasilkan suatu keputusan yang efektif dan berkualitas bagi organisasi, baik peserta maupun pemimpin selaku pembuat keputusan.

Di satu sisi, pembuat keputusan harus benar-benar berpikir tentang tujuan, aliran informasi serta peka dalam membaca kondisi atau masalah yang sedang dihadapi, sehingga dapat menentukan gaya kepemimpinan apa yang paling tepat dalam proses pengambilan keputusan. Di sisi lain, keanekaragaman individu dan nilai-nilai yang dipegang dalam kelompok membuat peserta yang ikut serta dalam proses pengambilan keputusan harus mampu menyadari mengenai perbedaan yang dapat terjadidi antara pesertaserta terbuka terhadap perbedaan dan keputusan yang diambil. Keseimbangan ini diharapkan mampu memberikan solusi terbaik dalam proses pemecahan masalah sehingga keputusan terbaik dapat diambil oleh pembuatkeputusanuntukmeraihpencapaian tujuan organisasi secara lebih efektif demi kesuksesan organisasi. 


\section{DAFTAR PUSTAKA}

Aziza, Kurnia Sari. 2015, 10 Januari.PT JM: Ahok Tidak Pernah Rapat dengan Kami. Kompas.com. Diperoleh dari

htt p: / / megapolitan.kompas.com/ $\mathrm{read} / 2015 / \mathrm{ol} / 10 / 21145591 / \mathrm{PT}$.JM.Ahok. Tidak.Pernah.Rapat.dengan.Kami

Chmielewski, C. 2004. The Importance of Values and Culture in Ethical Decision Making.NACADA Clearinghouse of Academic Advising Resources. Diperoleh dari

http://www.nacada.ksu.edu/Resources/ Clearinghouse/View-Articles/Valuesand-culture-in-ethical-decisionmaking.aspx

Curtis, Dan B., Floyd, James J. Jerry L. Winsor, 2005.Komunikasi Bisnis danProfesional. Bandung: PT Remaja Rosdakarya.

Davis, Keith. 1979. Human Behavior at Work. USA: MacGraw Hill Publishing Company Ltd.

Enayati, Jasmin. 2002. The Research: Effective Communication and Decision-making in Diverse Groups. Diperoleh dari http:// www.earthsummit2002.org/msp/book/ chap5.pdf

Griffin, EM. 2003. A first Look at Communication Theory. USA: McGraw Hills Company Inc.

Hasan, Iqbal. 2002. Pokok-pokok Materi Teori Pengambilan Keputusan. Jakarta: Ghalia Indonesia.

Laskito, Irfan., Mukti, Fajar Ginanjar. 2015, 9 Januari. Usai Temui Jokowi, Ahok Putuskan Proyek Monorel Batal. Viva News. Diperoleh dari http://metro. news.viva.co.id/news/read/576635usai-temui-jokowi--ahok-putuskanproyek-monorel-batal
Morissan. 2009. Teori Komunikasi Organisasi. Jakarta : Ghalia Indonesia.

Mykkänen, Markus., Kaja Tampere, Kaja. 2014. Organizational Decision Making: The Luhmannian Decision Communication Perspective. Journal of Business Studies Quarterly Vol. 5 (4).

O'Hair, Dan., Friedrich, Gustav W., Dixon, Linda Dee. 2009. Strategic Communication in Business and the Professions, edisi keenam, penerjemah Tri Wibowo BS. Jakarta: Kencana Prenada Media Group.

Pace, R Wayne., Faules, Don F. 2013. Komunikasi Organisasi. Bandung: PT Remaja Rosdakarya.

Priyatna, Soeganda., Ardianto, Elvinaro. 2008. Komunikasi Bisnis: Tujuh Pilar Strategi Komunikasi Bisnis. Bandung: Widya Padjajaran.

Robbins, Stephen. P. 2002.Prinsip-Prinsip Perilaku Organisasi. Jakarta: Penerbit Erlangga.

Seidl, D. \& Becker, K. 2006. Organizations as Distinction Generating and Processing Systems: Niklas Luhmann's Contribution to Organization Studies. Organization, 13(1), 9-35. 